\title{
1. Understanding low-income debt in a high-income country
}

Mia Gray, Katharina Möser and Jodi Gardner

The relationship between debt and crisis is at the very foundation of this book. Over the last ten years, many scholars have explored the 2008 global financial crisis that led to severe austerity policies in the United States (US) and many European countries and, in turn, exacerbated an "inequality crisis", a "housing crisis", and certainly a "low-income debt crisis" (Slater, 2016; Donald and Gray, 2019; Spooner, 2019). As this suggests, problems surrounding debt are expressed in many policy areas and on many different scales (Peck, 2014; Streeck, 2014). We ask how debt has become so problematic for so many people, especially those already struggling financially. This book explores the ways in which debt became interwoven with the international finance system, the nation state, local governments, legal and welfare systems, households, and the personal and intimate lives of people on low incomes.

We argue that academics and policy makers need to be sensitive to the mobility of debt - the institutional transmission mechanisms through which the burden of debt is reconfigured, repackaged, and pushed onto others. This mobility includes the increasingly "innovative" ways in which debt is traded on global markets; how debt is downloaded from one level of governance to another; the ways in which private debt is transformed into public debt; and the ways in which governmental debt becomes personal debt. Through these types of transmission, debt becomes problem debt for the most vulnerable in our societies - regardless of whether it is a public or private sector creditor. There is nothing inevitable about this transmission; the mobility of debt reflects political decisions about where and how the burdens of debt are distributed. And, of course, the Janus-faced nature of debt means that its transmission remain extremely profitable through credit-led accumulation strategies of the private sector, who often lend at exorbitant interest rates. This book explores the politics and geography of debt and examines the infrastructure of debt - in international institutions, such as the World Bank and the International Monetary Fund (IMF); in sovereign nation states, such as the United Kingdom (UK), Ireland, the US, and Sweden; and at a subnational level, through departmental decisions and local governments. We do this by examining the political 
economy of debt, the infrastructure which has been built up around debt, and crucially, possible policy and advocacy responses to low-income problem debt.

Although this book examines debt through the lens of austerity - the shrinking state budgets which lead to economic, social, and often political restructuring - we find ourselves in another episode of tumultuous economic and social change after the global financial crisis of 2008. This book is inevitably influenced by the emerging economic and social fallout of the COVID19 pandemic. Much of the book was written and rewritten during the outbreak in the Spring of 2020, when the editors and authors experienced, what was for many, a different rhythm to their working lives. More importantly, the themes explored in the chapters - such as the sharp rise in government debt following the financial crash of 2008, the uneven and unequal burden of the shrinking state, and the transmission of debt to the most vulnerable members of society - are likely to be experienced again, and in an exacerbated form. It is important to recognise that these "system shocks" have been seen before, even if each shock is always contingent and expressed in specific ways. Clearly, the debt levels of governments across the world have risen sharply in response to the pandemic, and will certainly continue to do so. The US, the $\mathrm{UK}$, and the EU are already increasing borrowing as well as creating money as part of their responses to this crisis. We also know that austerity measures are often invoked as a response to financial crises (Donald et al, 2014). This is a crucial time to examine the past experiences of rising levels of state debt and dissect the ways in which it was transformed into personal debt, particularly in low-income households. We think there are lessons to be learned by holding the last financial crisis up for close examination.

\section{HOW DID WE GET HERE?}

The circulation of debt - the constant churning of debt through global financial systems, its movement between and within countries, and the intersections between its public and private forms - is a longstanding theme in political economy approaches to understanding the uneven development of markets, states, and power. Financialisation, the increased importance of capital markets in turning the material economy into financial assets to be traded on global markets, is key to understanding how debt circulates in global markets (Pike and Pollard, 2010). The contemporary creation of new housing, urban infrastructure, and student loans are all examples of how the material economy is often as much about generating tradeable financial assets in global markets as responding to local demand (Pike et al, 2019; Aalbers, 2016). Scholars comment on the startling growth of traded assets in the run-up to the global 
financial crisis of 2008, and the importance of these flows to the UK and the US. Pike and Pollard highlight

the sheer extent and weight of financial trading activities and attendant practices of calculation and 'financial engineering' have surged through the activities of these (financial) institutions, growing exponentially in their geographic scale and scope and dwarfing output growth, especially in strongly market-led economies like the United States and the United Kingdom (2010: 33).

This expansion in financialisation involved both tradtional institutions (such as banks and international financial bodies) and new financial intermediaries (such as hedge funds and private equity firms), the later which increased in importance, visibility, and influence on financial markets. Through these financial actors, debt incurred for domestic infrastructure or commercial urban real estate could be transformed into tradable asset-backed securities on global stock markets (Pike et al 2019).

Many scholars highlight how financialisation was fundamental in underpinning and amplifying the effects of the US sub-prime mortgages debacle throughout the global financial system (Blyth, 2013; Aalbers, 2016; Dymski, 2012). A series of changes in financial regulation weakened regulatory structures intended to prevent excessive risk taking (Blyth, 2013). This deregulation enabled financial actors to create new financial instruments which obscured the true level of risk in a bundle of traded debt, and led to the erosion of mortgage lending standards in the US (Aalbers, 2009; Blyth, 2013). Scholars show that these measures extended the US mortgage market to include low-income clients, and encouraged predatory risky lending (Aalbers, 2016). However, Harvey reminds us that the speculative activity was by no means confined to the US, highlighting that "overinvestment and speculative activity in the housing and property markets in Spain, Ireland, Britain, and elsewhere, complemented the bursting of the US housing bubble" (Harvey, 2012: xv). This is reflected in Figure 1.1, which uses IMF international data to show both the general trend of increased household debt as a percentage of GDP between 1990 and 2010 as well as the different trajectories in individual countries. The data shows both the build-up of household debt before the financial crash and, with a small time-lag, the reduction of total household debt in many countries, as better-off households repaid outstanding liabilities.

This speculative activity in financial markets was certainly not confined to housing. Consumer credit (e.g. car loans, credit card debt, student loans, etc.) grew rapidly in the decade before the global financial crisis, and was also converted into credit derivatives on global markets. Many argued that consumer debt replaced the state in stimulating demand, and fuelled the economic boom experienced before the financial crisis (Spooner, 2019; Kitson et al, 2011). 


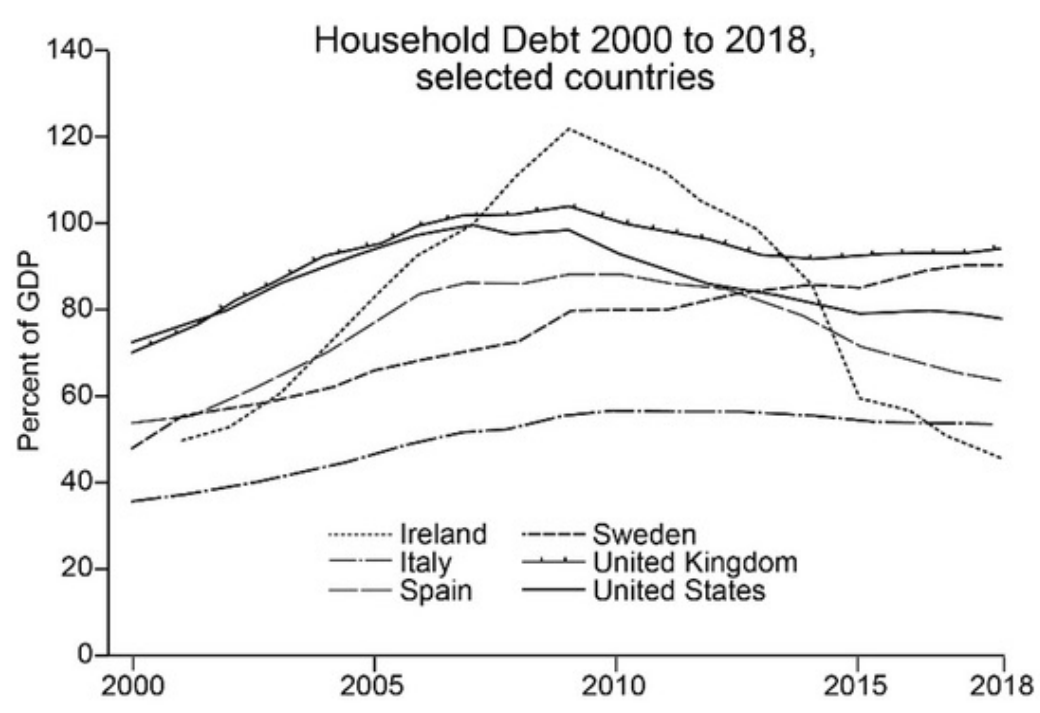

Source: IMF (2020).

\section{Figure 1.1 Growth of household debt}

A quick examination of the student loan industry highlights this concerning trend. In the US, and to a lesser extent in other countries, growing personal indebtedness was fuelled by the large amounts of money borrowed by students to pay university fees (Tabb, 2014; Goodnight et al, 2015). By 2019 student debt, at $11 \%$ of the total consumer debt, had become the second most important type of debt in the US, after mortgages. It also has the highest rates of loan delinquency rates, exceeding the same measure on credit card debt (Center for Microeconomic Data, 2020). Debts for the burgeoning private university sector are of particular concern in the US. Private universities are a lightly regulated sector, which grew spectacularly over the last 20 years, and had loans increasing from $\$ 3$ billion in $1997-8$ to over $\$ 19$ billion in 2007-8 (McClanahan, 2011: 59). Ross (2013) argues that the US federal government has effectively pulled out of funding universities and has therefore transferred fiscal responsibility from the state to individual students. This has occurred without ensuring there are adequate safety nets or consumer protection regulations in place. Likewise, Christopherson and colleagues argue that high levels of student loans reflect the extent to which higher education was politically recast as a private good where students gain financially from their individual 
investment in human capital, rather than a society benefiting from investment in a collective good (Christopherson et al, 2014). The sharp increase in student loans meant that during the same period that the subprime market in home mortgages boomed, "finance lenders" emerged as a major player in the student loan market. Thus, similar to the process surrounding subprime mortgage securitisation, student debt in the US was bundled with other kinds of loans and traded on secondary debt markets as collateralised derivatives. The financial crisis originated in the repackaging and rebranding of risky debt, such as sub-prime mortgages and student loans, and when many of those debts went bad, the repercussions rapidly ricocheted around the financial system. The mobility and fungibility of debt created a global financial crisis (Konzelmann et al, 2016).

In response to the 2008 global financial crisis, the UK government, like those of many other countries, pursued emergency fiscal stimulus measures and bank bailouts to avert collapse of the financial system (Konzelmann, 2019; Kitson et al., 2011). Years of "quantitative easing" followed through which central banks bought government bonds and corporate "toxic" debt. In many ways the public safety net, which had been shrinking as a mechanism of popular redistribution, had not disappeared but was "placed under the banking system" in a fashion that "was unprecedented in scale and duration" (Plender, 2020). Public sector debt in the UK went from $40 \%$ of GDP before $2006 / 07$ to $85 \%$ of GDP in $2017 / 18$ (ONS, 2018). Similarly, government debt in the US rose from $60 \%$ of GDP in 2007 to almost 100\% in 2018 (Faria-e-Castro, 2018). In this way, private sector debt was transformed into a sovereign debt crisis in what Blyth (2013: 73) called the "greatest bait and switch in modern history." Debt as a proportion of GDP increased in all the countries highlighted in this book (Figure 1.2). This public debt was due to these policies to bolster banks and the global system of finance, rising demand for social protection and welfare after unemployment rates jumped in most OECD countries, and from weak economic growth after the crisis. We can also see the variation between countries and that some states, such as Italy, had a history of indebtedness before the financial crisis which exacerbated their problems afterwards. These national overviews to some extent hide as much as they reveal. Donald et al (2014) show that broader national policies were translated into a diverse landscape of austerity, with some cities and regions more affected than others. Austerity was not an inevitable response, with scholars highlighting the initial 12 months of Keynesian stimulus spending in many countries (Kitson, 2011; Konzelmann, 2019) and divisions with the economics discipline over stimulus versus "expansionary contraction" (Krugman, 2015; Stiglitz et al., 2014; Reinhart and Rogoff, 2009 \& 2010; Alesina and Ardagna, 2010; Herndon, Ash and Pollin, 2014). However, consensus around austerity was pushed by many national governments, such as in the UK, and by international institutions 


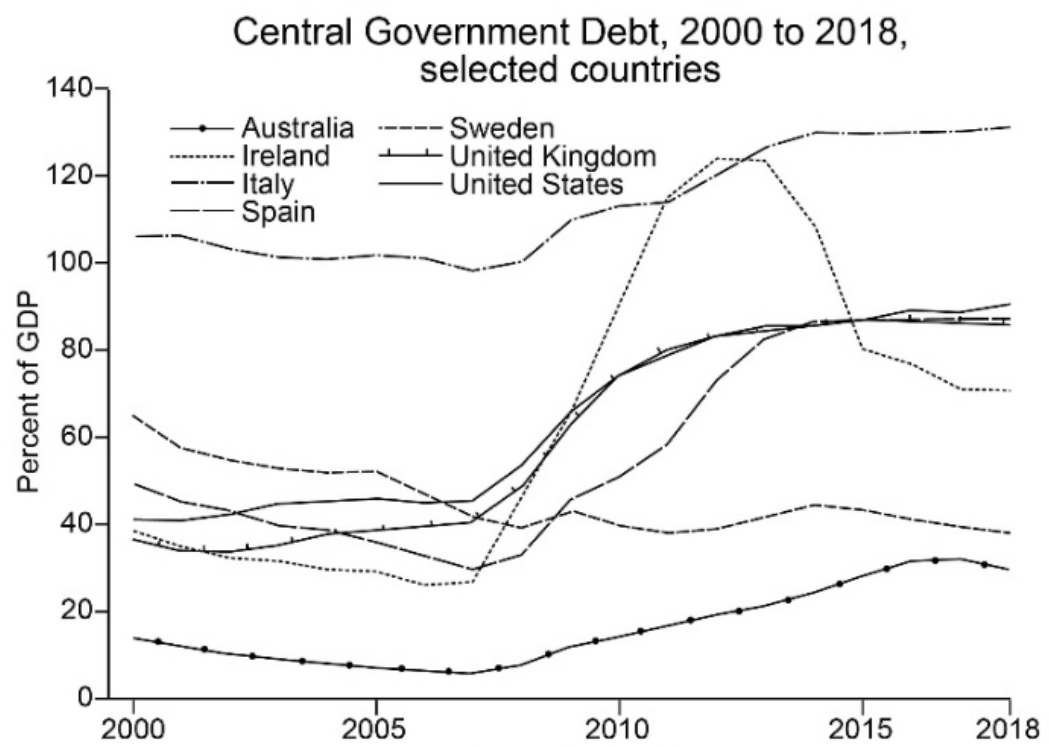

Source: IMF (2020).

\section{Figure 1.2 Growth of government debt}

such as the European Commission, the IMF, and the European Central Bank. These institutions saw sovereign state debt as potentially economically and politically destabilising, and imposed austerity policies as a precondition for financial aid (Clifton et al, 2018). Many academic and policy observers argued that austerity was more political than economic - that austerity was part of a longer-term political project to promote a permanent smaller state, a more neo-liberal state (Clifton et al, 2018) and to redefine the redistributive function of the welfare state (Hamnett, 2014). In this account, reducing public debt was synonymous with shrinking the state (Blyth, 2013; Boyer, 2012; Peck, 2014; Streeck, 2014). Finally, some countries such as Canada, which did not experience a large increase in public debt because their banking system was more heavily regulated, still borrowed the narrative of "prudent spending" from their neighbours and underwent a form of "hidden austerity" (Donald and Gray, 2017).

Rarely did austerity policies remain at the central government level, but were often pushed down to the local level, where tough decisions about the distributional aspects of the cuts were forced onto local government (Peck, 2014; Hastings et al, 2017). This, in effect, functioned to displace the financial 
crisis to lower spatial scales of government, non-governmental actors, and low-income households (Brenner, 2004; Theodore, 2020). Within the context of the UK and US, austerity was pushed down to the poorest areas in the country, which were dependent on redistributive grants from central government in a way which increased "spatial injustice" (Gray and Barford, 2018; Hastings et al, 2017; Peck, 2014).

\section{UNDERSTANDING THE INTERPLAY BETWEEN DEBT AND AUSTERITY}

Public and private forms of debt are deeply and intimately intertwined. Issues of debt are interwoven into the structure, regulation, and functioning of the international financial system and the nation state. Similarly, the interplay between forms of public and private debt are expressed through the workings of local governments, legal systems, and welfare systems. Households and individuals, often on low-incomes, in turn both affect and are affected by the regulation, structure, social acceptability, system of enforcement, and cost of debt. The state itself, at national and local scales, is fundamentally important in understanding these relationships. This section teases out these multiple relationships between debt and austerity.

\section{Shrinking of the Welfare State}

Austerity measures have intensified and enabled the erosion of many important pillars of the welfare state, in what Banting and Myles (2013) characterise as "the fading of redistributive politics". This is true across many European countries and in the US, including paradigmatic welfare states such as Sweden (Svallfors and Tyllström, 2019). Within the UK, the Welfare Reform Act 2012 followed quickly upon the heels of austerity. In countries such as Greece, Portugal, and Cyprus, the "Troika" (the European Central Bank, the EU, and the IMF) demanded reductions in welfare systems as a condition of economic support during the financial crisis (Clifton et al, 2018). Thus, just as the economic downturn after the financial crisis heightened the need for social welfare provision, the state shrunk its redistributive focus - leaving the unemployed, the disabled and the sick, and pensioners with large holes in their social safety nets.

For some, equity in homeownership can function to fill the hole in the safety net. Smith's chapter highlights how the spread of mortgages and home ownership have created a benchmark for the acceptability and normalisation of debt. As part of this, housing wealth, or "asset-based welfare", may function to fund social protection throughout the lifecourse - offering options around education, health and elderly care not available to those dependent on the public 
safety net. Lowe and colleagues (2012) argue that many homeowners "bank" on their homes' equity as a type of individualised financial safety net. This individualised safety net is enabled, and increasingly expected, by the state, and is used by households to fund pressing, short-term spending needs (Wood et al, 2013). But long-term needs may also be funded this way. The increased state eligibility requirements attached to many benefits (e.g. adult social care) mean many are forced to use their home equity to cover the shrinking social provision of welfare (Lowe et al, 2012). Montgomerie and Büdenbender (2015) show that expecting housing to function this way depoliticises the uneven ways in which asset-based welfare intensifies household indebtedness.

Many others will turn to a diminished welfare state for help. In this book, the chapters by Gray, Gardner, and Davies and Finney explore the changes to the UK system of welfare provision in greater detail. Social protection budgets have experienced severe cuts. Between 2012-13 and 2016-17, the UK reduced the support for unemployment benefits, family benefits, income support, tax credits, and housing benefits. The cuts to unemployment benefits increased the intensity of conditionality, tightened eligibility, and enforced a regime of sanctions. These reforms function to push people into employment, no matter how weak the local labour market or precarious the job.

In the UK, there was a short-lived ideological justification for the shrinking of the state in the form of the "Big Society" - a celebratory account of community provision of public services. This was intended to push responsibility for the social safety net from the state towards the general public. One of the clearest examples of this is the increased reliance on food banks for basic sustenance, covering the many holes in the current welfare system and the precarious job market. The Big Society was dismissed by many as merely a cynical attempt to justify spending cuts (Kinsby, 2010: 485), and an independent review concluded that the Big Society has "largely failed" (Slocock et al, 2015: 8). One of the most negative aspects of the movement was the transfer of government services to the voluntary sector, and the consequent reduction in funding. As a result, the voluntary sector lost $£ 1.3$ billion of state funding in 2011-12 alone. These drastic cuts were not replaced by an increased contribution from voluntary or charitable organisations. Prior to the Big Society, these organisations were already struggling to meet the demands of the public, experiencing cuts to their own budgets and, post-Big Society, formal volunteering and community social action actually declined (Slocock et al, 2015: 25). Whilst this had negative outcomes across the board, smaller organisations and services to disadvantaged groups were impacted to the greatest extent (Slocock et al, 2015: 32). 


\section{Universal Credit}

The UK's welfare reform programme, Universal Credit, is also inherently linked with issues of austerity and debt. The programme simplifies a number of separate benefits into one, pushes work as a solution to poverty, and tapers state benefits according to the previous month's income. It stems directly from austerity measures and the UK government's desire to have work, not state benefits, underpin anti-poverty measures. The problems created by Universal Credit are the underlying cause of many of the complex debt issues covered in several chapters, including those by Strong, Gray, Rowlingson, and Davies and Finney. The UK Government has commented that:

Universal Credit is revolutionising the welfare system by making work pay. The design and structure of Universal Credit is transformational, it focuses on replicating the world of work, encouraging claimants to take greater responsibility for their finances and incentivising them to earn more and progress in work ... Universal Credit is already transforming lives and evidence shows people are moving into work faster and working longer with Universal Credit than under the old system (DWP, 2017: 1).

As positive as this may sound, Universal Credit is widely considered a drastic failure, causing widespread suffering for many people and exacerbating extreme poverty (Alston, 2019a). There have been significant issues with how the reforms have been carried out, which has been costly to both the government and the people reliant on the benefits for survival.

Some observers argue that the structure of Universal Credit has pushed many people on low incomes into debt. One issue is the immediacy of debt and the lack of autonomy over debt repayment. The digital nature of Universal Credit allows the state to automatically deduct overpayments of benefits, from the previous month or from years past (Alston, 2019b). The state can also take deductions from monthly benefits in order to repay "advances" or to rectify payment mistakes. A 2017 report from Citizens Advice found that people in receipt of Universal Credit were more likely to have priority debts and to struggle with rent and council tax arrears, and had less available income to pay creditors (Drake, 2017: 8-11).

These problems arise from the structural features of Universal Credit, including the five-week wait for the initial payment (Alston, 2019b). As the payment levels can be set to an extremely low level and are designed to provide individuals with only the social minimum, this wait automatically pushes recipients deeper into poverty. It is one of the main reasons for the current unprecedented demand on food banks. During this period, many people have no available income and therefore rely on credit to cope with day to day life expenses. It is a particularly harmful aspect of the new regime, and ensures that 
- unless they have sufficient savings to cover their expenses during this entire period - recipients will have to go into debt just to survive. As Gardner, Gray and Rowlingson's chapters discuss, people can receive an "advance" on their benefits to help them through this period which is then repaid by a reduction in future benefit payments, but repayment itself sends recipients into debt. This is one way in which the state itself has become a major creditor for many low-income people in debt and changes the state's fundamental role from social protector to creditor.

Obtaining high-cost credit is another alternative to taking a Universal Credit advance. This is often an even worse position - as the loan will have to be paid back from future benefits with interest, fees, and charges. Although Rowlingson's chapter reminds us that many people value these alternative forms of credit, others emphasise the harmful nature of this type of credit. Williams discusses the affordability issues associated with the lending criteria utilised to offer loans, Davies and Finney explain how it is one aspect of the detrimental poverty premium, and Gardner emphasises how these loans force already vulnerable people below the social minimum.

\section{Local Government and Debt}

As mentioned earlier, national governments are only one level at which the state is involved with austerity and debt. Local governments in the US, the UK, and other European countries are also embroiled in issues of austerity and debt (Donald et al, 2014). National programmes of austerity in many countries were pushed down to lower levels of government in a highly uneven fashion. Peck (2012) shows that an increasing number of public services are pushed onto local governments without a corresponding revenue stream, hence concentrating the tensions and politics of fiscal crisis onto these institutions. In this way, local governments become major actors in determining the distributional politics of austerity at the local level. In many ways their agency is constrained and contingent, but scholars have found that some local governments have been more able than others, and more willing to expend political capital, to shield their most vulnerable members of the community (Hastings et al, 2017; Davies and Blanco, 2017).

Nor are local governments merely passive recipients of austerity cuts - some have also actively taken on large debts themselves, turning to debt-financed municipal entrepreneurialism to increase their budgets and expand their political and economic options under austerity. While there is a long history of municipal entrepreneurism in US cities (Harvey, 1989; Davidson and Kutz, 2015), the model was only pursued on a large scale by local authorities in the UK with the imposition of austerity cuts. Some local authorities have taken out low-interest public sector loans to buy office buildings, shopping centres, 
and other commercial property, often investing outside their boundaries, in order to take on the role of property speculators themselves (NAO, 2020). The National Audit Office found that between 2016 and 2019, UK local authorities increased these often-risky investments 14 fold compared to the previous three-year period (NAO, 2020). This is what Beswick and Penny (2018) refer to as "financialised municipal entrepreneurialism", or the state-executed, speculative development and financialization of public land. This is also captured by Pike and colleagues (2019) as they highlight the striking increase in UK local governments' involvement in new financialised economic strategies, instruments, and commitments.

Unfortunately, local government's track record in municipal entrepreneurialism has not always been strong. After the 2008 financial crisis, a number of US cities and municipal services entered bankruptcy (Peck, 2014), including Detroit in 2013 (Reese et al, 2014; Hall and Jonas, 2014), Valejo in 2008 (Davidson and Kutz, 2015), and San Bernardino and Stockton in 2012 (Davidson and Ward, 2014). Although Detroit was distinct in the size and scale of debt, many cities shared the problems of falling federal revenues and declining property taxes. Some cities, such as Valejo, had borrowed heavily to finance years of speculative investment. The rising cost of servicing this debt and the timing of repayments spelled disaster for the city when the global financial crisis hit. The UK has also had its own example of post-crash municipal fiscal crisis when Northamptonshire County Council issued a section 114 notice and effectively declared itself bankrupt in 2018. This process resulted in radical service cuts as the Council adopted the legal-minimum level of service for residents. Although Northamptonshire is the sole contemporary example of municipal bankruptcy in the UK, the "threat" of bankruptcy underlies many political decisions and functions to "fiscally discipline" cities (Peck, 2012). The next section explores the increased role of the local state as creditor.

\section{The State and the Changing Composition of Debt}

The nature and composition of credit in the UK has changed fundamentally during the decade since the global financial crash. Debt in the UK, and particularly low-income debt, is shaped by new actors and new regulations. As outlined by Williams' chapter, the enforcement of commercial consumer credit has received considerable media attention recently, particularly with the exploitative actions of certain lenders and their subsequent downfall. While there is more regulation of high-cost credit contracts, and some major firms have left the industry, exploitative practices around low-income debt remain a problem. There are a number of chapters in this collection that focus on high-cost credit, such as the contributions by Williams, Rowlingson, 
Gardner, and Henrikson. This is, however, only part of a very complex debt environment.

Citizens Advice highlights what they call "the hidden problem of household bill debt". These debts are for essential services (including fuel, water, and telecoms), rent arrears, debts to government (such as council tax arrears or overpayments of tax credits), and fines or penalty notices (Lane et al, 2018: 4). In 2017-18, Citizens Advice received almost 700,000 complaints about these debts - nearly double the complaints received about commercial consumer credit (Lane et al, 2018: 7). The increase stems from five key debts - council tax arrears, rent arrears, tax credit overpayment, unpaid parking fines, and Magistrate fines (Lane et al, 2018: 8). Out of these, council tax arrears were by far the largest cause of concern, making up approximately one-third of all the complaints. Whilst there are no overall statistics on the total amount of this type of debt, the Citizens Advice Bureau estimated that in 2017 over $£ 19$ billion was owed to government and essential services providers, a $34 \%$ increase from 2010 (Lane et al, 2018: 13). The main sources were tax credit overpayments, council tax arrears, and benefit overpayments - again reinforcing the point that the state (at a national and local level) is playing the role of dispenser of welfare, while also becoming a major creditor (Lane et al, 2018: 14).

Household bill debt creates several specific challenges for regulators. Crucially, the creditors are the government and not private institutions. This creates an inherent conflict of interest when determining how to regulate the creation and collection of these types of debts. In addition, the people who have outstanding household bill debt are more likely to be vulnerable, including being unemployed, single parents, struggling with mental health challenges, and/or living in council housing (Lane et al, 2018: 17). Household bills are also frequently overwhelming "priority debts", which have severe consequences if they are not paid including the cutting off of essential services, eviction, or future benefit reduction (The Centre for Social Justice, 2020: 17).

The UK state also utilises heavy-handed and exploitative mechanisms to recoup as much money as possible out of those who can least afford it, and this will be discussed in more detail below. The extent and severity of the situation was recently outlined by the Centre for Social Justice, which provided disturbing examples of how "government debt collection continues to lag significantly behind that of the private and regulated sector" (The Centre for Social Justice, 2020: 8). In many other aspects of society, such as employment practices in the public sector, the government promotes and follows "best practice". This approach can and should be extended to debt collection mechanisms, which is clearly not happening. It is crucial that the government rethinks its debt collection processes; the recommendations from the Centre for Social Justice to "embed fairness across all of government debt collection" 
are an excellent starting point for this discussion (The Centre for Social Justice, 2020: 62). In addition to the different types of debts, low-income individuals often pay more for the same basic goods and services. This harmful "poverty premium" exacerbates the difficulties experienced by many low income families and is discussed in more detail in Davies and Finney's chapter.

\section{Legal Aid}

The dramatic fall in access to legal aid is intertwined with many issues considered by this book. Shortly after imposing austerity, the UK fundamentally restricted the availability of legal aid around issues of debt. The Legal Aid, Sentencing and Punishing of Offenders Act 2012 (UK) or 'LASPO' removed legal aid in many areas, including debt, most welfare benefit cases, general consumer complaints, housing matters that did not constitute "an immediate risk to the home", family law cases without proof of domestic violence, forced marriage, and child abduction. LASPO has been significantly criticised by a wide range of stakeholders, including House Committees, as vividly summarised by Prescott (2018):

Whatever perceived savings are attributed to these cuts are outweighed by a greater human and social cost. It has cut away at the last recourse people have against an increasingly hostile system and we all live more precarious lives because of it. The LASPO Act undermines the human right to a fair trial in the UK and entrenches the power and privilege of those who can afford the cost of legal representation.

In 2018 the Bar Council of England \& Wales published Justice in the Age of Austerity, which examined the impact of austerity budget cuts on access to justice from 2008 to 2018 (Chalkley, 2018: 4). The author comments that this "decline in resources will be reflected in a decline in the volume and quality of the justice system and access to it" (Chalkley, 2018: 15). The impact of cuts in funding to legal aid has not however been equally felt across the country, with already disadvantaged regional areas being the worst hit.

Access to justice was further debilitated by the closure of Magistrates Courts; austerity and subsequent government cuts have meant that, in less than a decade, half of all Magistrates Courts in England and Wales have closed (Bowcott and Duncan, 2019). This has often forced individuals to either give up their claims, not defend claims against them, or attend Magistrates Courts in "regional hubs" located in neighbouring cities, presenting an increase in the time and money needed to attend court. This is yet another obstacle in the way for low-income individuals to challenge unfair processes and rulings.

The United Nations Special Rapporteur on extreme poverty and human rights condemned what it described as the "decimation" of legal aid in the UK. 
Alston reported that the reduction in access to legal assistance has prevented those most vulnerable in society from claiming and enforcing their rights. This has wider ramifications, as "lack of access to legal aid also exacerbates extreme poverty, since justiciable problems that could have been resolved with legal representation go unaddressed" (2019a: 10). The most vulnerable people in our society are therefore experiencing a perfect storm of disadvantage the contraction of the national and local state safety nets, the fundamentally flawed Universal Credit system, rising costs of living, increasing debts to the government and private creditors, and aggressive enforcement of these debts - that are all occurring at a time where access to justice is being severely undermined. Therefore, even if these individuals had legal rights that they theoretically could enforce, there are severe practical and financial hurdles preventing them from achieving any sort of justice.

\section{THE INFRASTRUCTURE OF DEBT}

The social and economic infrastructure of debt is relevant to many issues discussed in the book, such as consumer credit regulation, debt relief, debt advice, debt enforcement systems and, more recently, credit scoring. Low-income individuals often interact within a particular institutional set-up - the legal structure, the private sector firms, the charity providers, the "intermediaries", the debt collection industry - which goes far beyond the initial relationship between debtor and creditor. Although this debt infrastructure is contingent, it has often been shaped by ideological beliefs and assumptions. Some models focus on the consumer debtor as a rational, utility maximiser from neo-classical economics, or at best an over-optimistic and impulsive individual who values the present over the future, while other models highlight structural constraints (see, for example, Block-Lieb and Janger, 2005-06; Sunstein, 2006; Bar-Gill, 2004; Elgueta, 2014; Möser, 2019).

Spooner's chapter examines Irish Insolvency Law reform, outlining how policy makers were preoccupied with a fear of creating a moral hazard (i.e. debt relief would encourage non-payment of debts). Spooner shows how, based on these assumptions, the design of Irish debt relief laws focused on the need to maintain "debtor discipline", thereby seeking to avoid threats to financial stability. Likewise, Henrikson analyses high-cost credit regulation in Sweden, suggesting that the debtor image has changed from an active and rational individual to one with potential behavioural weaknesses. Henrikson is however positive about increased consumer protection in Sweden. This can be contrasted with Gardner who analyses the issue of high-cost credit in the UK context, arguing the most effective response to the challenges of low-income debt is the reduction of existing inequalities. She argues that increasing paternalistic government regulation does little to address the cause of the 
problem - namely the demand for high-cost loans. Thus, Gardner asserts that austerity-based structural inequality, rather than behavioural problems on the part of the debtor, is the underlying cause. These structural inequalities are also considered in more depth by Rowlingson in her chapter.

\section{The Concept of Bankruptcy and the Increased Use of Privatized Alternatives}

The book also explores the theme of bankruptcy and debt relief, including bankruptcy of financial institutions at the start of the 2008 financial crisis, local government bankruptcy, corporate bankruptcy, and personal bankruptcy. Although bankruptcies in all forms have increased, personal bankruptcy among low-income households has been particularly problematic. This is, in part, due to upfront fees preventing access to bankruptcy procedures and the narrowed access to legal help navigating the complexities of bankruptcy alternatives.

At its core, personal bankruptcy is a legal concept, denoting various statutory debt relief procedures which provide a refuge for increasing numbers of financially troubled households. In the context of England and Wales, such statutory debt relief is provided by traditional bankruptcy procedures, but also by the Debt Relief Order (DRO) procedure, which provides a simplified process for so-called "no-income, no asset" debtors. These mechanisms cancel personal debt and minimise or revoke on-going repayment obligations. In this way bankruptcy as a debt relief measure re-allocates the costs of over-indebtedness from the debtors to creditors. Creditors can, similar to an insurer, use interest rates to impose a risk-adjusted premium, and are able to internalise the risk of financial failure (Hallinan, 1986: 103-9; Spooner, 2019: 93-7). By providing such a mechanism, bankruptcy is of essential importance to reviving an economy in the aftermath of financial crisis. It prevents the so-called "debt overhang" effect, under which high levels of household debts force households to use substantial amounts of current and future income for the repayment of past debt, leaving limited resources available to contribute to economic growth (Mian and Sufi, 2014; Spooner, 2019). Also, this re-allocation mechanism incentivises responsible lending and accounting by creditors (Ramsay, 2017; Spooner, 2019).

However, personal bankruptcy is becoming more difficult to access. A recent comparative study of national insolvency laws concludes that "liberal access to straight bankruptcy with a relatively swift discharge is an increasingly 'suppressed political alternative"' (Ramsay, 2017: 5). Reflecting this, Spooner's chapter shows, in the context of Ireland, an increased reliance on "market-based debt resolutions", based on a consensual renegotiation between debtor and creditors. Crucially, these make debt relief dependent on 
the completion of a long-term plan, where repayment obligations must exceed those under the standard bankruptcy procedure. Similar observations arise from Möser's analysis of the debt relief system in England and Wales. She describes the increased use of privatised alternatives to bankruptcy, such as Individual Voluntary Arrangements (IVAs), with long-term repayment obligations, which are often more extensive than those imposed by statutory debt relief procedures.

This move towards privatised mechanisms of debt reduction is a problem, as it reduces the re-allocative effect of debt relief, thereby impairing its beneficial economic effects. In particular, privatised debt relief systems are inadequate and ill-suited to meeting the challenge of rebuilding our economy in the aftermath of the current COVID19 crisis (Pistor, 2020). Both Spooner and Möser look into the reasons for these developments. Spooner refers to the increasing political influence wielded by financial sector interests, as well as aforementioned concerns about moral hazard among Irish debtor households. Möser suggests that the privatisation process of debt relief procedures may also promote self-interested concerns in central government and the bureaucratic elite. Montgomerie's chapter responds to these limitations by recommending a more radical debt cancellation process for low-income households.

To navigate complex debt resolution systems, consumer debtors often rely on advice services, which exert determinative influence over consumers' choice of remedy as intermediaries (Ramsay, 2000; Ramsay, 2003). However, the interests of these intermediaries often diverge from those of the consumer, meaning that they may advise debtors in a way that best serves their interests (Spooner, 2019: 155-6). This conflict of interest is most obvious in the provision of for-profit debt advice. In prioritising their commercial interests over the best interests of their clients, some debt advice agencies divert debtors into privatised debt resolutions, when in reality one of the public debt relief solutions would have been more appropriate. Also, some debt advice agencies are not effective at identifying when consumers are unrealistic about their ability to meet the payment requirements of privatised debt resolutions. Indeed, the Financial Conduct Authority (FCA) describes instances of providers deliberately misrepresenting the disposable income of consumers. Austerity measures have exacerbated these issues. Well-established advice institutions, such as the Citizens Advice Bureaux, have experienced major funding cuts, leaving the UK with an increasingly fractured debt advice system that in large part depends on private funding.

There are two basic funding models in low-income debt advice. The first model, often used by private debt advisors, imposes fees on the consumer debtors, which are deducted from the monthly repayments that these debtors make to their creditors. Additionally, these commercial providers typically charge a substantial one-off set-up fee and a regular management fee. An 
alternative funding model, used by major charitable organisations such as StepChange Debt Charity, is based on creditor contributions, which are made on a pro-rata basis according to the amount of debt repaid through formal repayment plans. Crucially, both models might create incentives for debt advice agencies to steer debtors into income-generating long-term repayments, rather than statutory debt relief solutions, as these provide them no or little income.

Some of the privately funded debt advice agencies are now under the direct regulatory control of the FCA, whilst other parts of the industry, such as IVA providers, are only subject to a self-regulatory regime (Insolvency Service, 2019). Möser's chapter highlights these issues. Building on the aforementioned FCA reports, she describes the mis-selling of IVAs by commercial providers and the long-standing regulatory failure to address this issue. Strong's chapter provides a nuanced picture of the support provided by Christians Against Poverty and examines the intimate complexities of personal debt, reminding us that consumption choices are as much a social issue as an economic one (Wherry, 2019). Gardner's chapter discusses this conflict in more detail. She argues that providing private market debt solutions to borrowers with problem debt is not the answer; the process merely creates opportunities for further exploitation of already vulnerable individuals.

\section{Stigma and Credit Scoring}

Debt is often associated with complex issues of guilt, shame, and stigma. These are most dramatically reflected in the fear of bankruptcy, as explored by the chapters of Strong and Sparkes. This association has been heightened under the logic of neo-liberalism, where moral responsibility for financial difficulties is placed squarely on the shoulders of debtors (Ramsay, 2017). In this vein, both chapters observe that after the financial crisis of 2008, government rhetoric was infused with negative moral connotations attached to financial profligacy of individuals, previous generations of politicians, and even some jurisdictions. Furthermore, Sparkes links the heightened stigma associated with financial failure to the introduction of wide-spread credit scoring systems, which appear to automatically translate poor financial habits and behavioural weaknesses into a downgrading of (credit-)worthiness. Similarly, the trend of long-term repayment plans fits the move towards increasingly coercive practices in the treatment of credit users.

The growing use of surveillance and sanctions may be understood in relation to what Wacquant describes as the "distinctive paradox of neoliberal penalty". That is, those governmental practices that celebrate the "free market" and individual responsibility, on the one hand, while deploying increasingly intrusive and punitive policies to protect the market, on the other (Wacquant, 
2009). Indeed, Sparkes' chapter argues that the UK government consciously uses corrective policies to ensure the health of the financial market. Gray's chapter also highlights financial surveillance in the welfare benefit system, which automatically extracts repayment from income, without recourse to affordability criteria.

\section{Practices of Debt Collection}

A fundamental part of the debt infrastructure is the changing debt collection practices, which can be aggressive, lacking in dignity, and exploitative. The use of private sector bailiffs is now the most common mechanism of collection of household debts (Lane et al, 2018: 18). This is of particular concern as many low-income debtors are often already vulnerable and can easily be coerced into unaffordable repayment agreements (The Centre for Social Justice, 2020). Thus, as local governments become more prominent as debt collectors under austerity, they are increasingly utilising bailiffs for debt enforcement. Money Advice Service estimated that in 2017, 2.3 million of the 2.5 million debts passed to bailiff firms were from local authorities (McDonagh et al, 2019: 3).

Citizens Advice estimates that one in three people contacted by bailiffs have grounds for a complaint regarding breach of applicable rules. This includes refusal to accept affordable payment offers, misrepresentation of rights of entry (for example, threatening to break into the house), taking control of goods inappropriately, acting aggressively, and finally, acting unsympathetically towards the vulnerable, especially people with illnesses and disabilities (Lane et al, 2018). It is also an exceptionally expensive form of enforcement - bailiffs are entitled to charge $£ 110$ for writing to an individual, $£ 235$ for visiting a debtor's house, and $£ 110$ for taking and selling belongings. A single process of debt enforcement could therefore cost an already struggling individual $£ 455$, and that is before any funds are actually used to pay off the pre-existing debt.

In light of these issues, in 2014 the UK's Ministry of Justice created additional obligations on bailiffs and provided clarity on maximum bailiff fees. Whilst the rules themselves were a step forward, enforcing these rules, making complaints, and ultimately taking the bailiffs to court remains exceptionally difficult and complex (The Centre for Social Justice, 2020: 58). In reality, vulnerable debtors who do not have the funds to pay outstanding debts and are being hounded by bailiffs, rarely have the financial and practical means to pursue redress. In the first four years after the 2014 obligations were imposed, there were only 56 statutory complaints made - of an estimated 1,600,000 rule infringements (McDonagh et al, 2019: 17). Unlike the consumer friendly and free to access Financial Ombudsman Service (FOS) for private debts and enforcement, there is no equivalent independent regulator for bailiff activity. 
This creates a regulatory gap between the rights that debtors have in theory and the rights that they can enforce in practice; a gap that is exacerbated by the impact that austerity measures have had on the legal sector and access to justice. Williams' chapter highlights the effect of affordability assessment obligations on the commercial high-cost credit sector. The enforcement of these legal obligations has resulted in the downfall of some of the biggest lenders in the industry. It is however highly unlikely to have occurred without FOS, as individual debtors would not have had the time or money to utilise traditional court mechanisms. Bailiffs have comparable obligations to undertake affordability assessments. There is significant evidence that, similar to commercial credit providers, bailiffs are not making adequate assessments. Unfortunately, the debtors who suffer from these breaches have restricted enforcement mechanisms, meaning that bailiffs have little incentive to change their behaviour.

\section{WHAT CAN BE DONE?}

There are an increasing number of ways to mediate between debtor and creditor in the private sector. Potential remedies to the tightening bind of low-income debt range from the incremental to the radical, from the quotidian to the extraordinary, from the prosaic to the poetic. One of the most effective ways to respond to the access to justice challenges is by increasing consumer friendly (and free to use) alternative dispute resolution. This allows impacted individuals access to remedies without utilising expensive and emotionally difficult court processes (see Creutzfeldt, 2018). When responding to potential claims against private institutions in the UK (such as high-cost credit providers, telecommunications providers, or airlines), there are a range of alternative dispute resolution processes - including various Ombudsmans, the Civil Aviation Authority, and the Communications and Internet Services Adjudication Scheme. These institutions are free to access, and make decisions not just on the legal obligations to consumers, but also duties of care and best practice requirements. For example, the Personal Finance Research Centre (PFRC) conducted an in-depth review of FOS, judging it "a thoughtful, well managed organisation that is doing a good job under difficult circumstances" (Kempson et al, 2004: 39).

Unfortunately, similar processes rarely exist for complaints about government decisions and public services. One exception to this is the Local Government and Social Care Ombudsman, which can consider complaints about housing benefits and council tax. As indicated above, there is also no independent regulator of bailiff activities. It also allows bailiffs to continue their questionable behaviour and breach national standards without any real fear of consequences. Appealing against government decisions on matters 
such as welfare payments and benefits overpayments also remains complex and often inaccessible. Austerity cuts have reduced the opportunities for people to seek assistance from not-for-profit organisations and, as discussed above, legal aid cuts have had a significant impact on general access to justice. This has created a "perfect storm" of disadvantage with no clear remedy. As the financial ramifications of COVID19 become more obvious and concerning, it is highly unlikely that there will be more funding available for these vital services in the near future. Therefore, one potential way forward is to create similar dispute resolution processes for government decisions and public services, providing appropriate consumer-friendly remedies whilst incurring significantly less public expense than traditional court mechanisms.

The UK could benefit from a consideration of the experiences and programs run by other countries. An example of this, outlined in Grace's chapter, is a unique partnership between a major Australian bank and a microfinancing not-for-profit organisation. The partnership competes with commercial payday lenders, and has provided no-interest or low-interest loans for tens of thousands of vulnerable Australians. These programs have enviable levels of success, with high repayment rates (95-6\% of loans being repaid), as well as $82 \%$ of clients experiencing improvement of their financial situation and $78 \%$ clients no longer resorting to commercial lending. Similarly, Rowlingson's chapter points to the potential of not-for-profit credit unions to offer a low-cost alternative to payday and home credit lenders.

In reality, the main solution for the multiple problems arising from austerity-related debt will be to tackle the underlying issues of inequality and poverty. It is unacceptable that such a wealthy, developed country with a proud history of welfare has such inconceivable levels of inequality and poverty. The situation is so concerning that, in May 2019, Great Britain and Northern Ireland was visited by the United Nations Special Rapporteur on extreme poverty and human rights. Whilst the findings of the report are clearly the basis for concern, the mere fact that someone whose job is to investigate "extreme poverty" visited the UK highlights just how dire the situation has become. The subsequent report was strongly critical of the austerity measures taken, stating that despite the UK being the world's fifth largest economy and having a "fundamentally strong" economy, one-fifth of the population lives in poverty and approximately 5\% are in extreme destitution. An additional 2.5 million people are less than $10 \%$ above the poverty line, just one financial hiccup away from falling into poverty. The Special Rapporteur also criticised the "shocking increase in the number of food banks and major increases in homelessness and rough sleeping [and] a growing number of homeless families", concluding that due to austerity measures "great misery has been inflicted unnecessarily" on the most vulnerable people in the UK (Alston, 2019a: 3-6). 
There are multiple steps the government can take to undo some of this misery: Stopping the use of the expensive, upsetting, and inefficient bailiff process to recover government debts. Restoring access to justice in the country by undoing the harm from LASPO, increasing access Legal Aid and ensuring that it covers welfare appeals and debt matters. Removing the restrictions on child benefits which only cover the first two children, as this penalises large families and pushes them into poverty. Reinvigorating the social fund as a lender of last resort. These are just a handful of recommendations, there are many others included throughout the chapters in this collection.

One of the most practical ways to improve the bottom line of many low-income households is by tackling the poverty premium. Davies and Finney's chapter outlines the range of reforms to reduce or eliminate the harm caused by this phenomenon. The authors note that positive steps have been taken, and it is particularly heartening to see that financial difficulty is formally recognised as a vulnerability. There have been movements towards reducing the premium with regulatory change involving the implementation of price caps on certain financial products (namely high-cost credit and rent to own products), and a closer regulation of energy market tariffs. The impact of the poverty premium could be further reduced by not allowing companies to penalise consumers for spreading payments of goods and services across a longer period of time, for example with car and home insurance. The authors also advocate for a wider policy environment that utilises "FinTech" to improve the financial resilience of those in vulnerable circumstances and increasing access to affordable credit.

Reforming Universal Credit will be another concrete way to tackle the harm created by unnecessary debt. As Gardner argues in this collection, the benefits system should not only provide the social minimum, but it should also maintain this level. The current five-week wait is doing exactly the opposite. People who apply for benefits should not be burdened by debt, either to the government or commercial providers. Evidence from an overwhelming number of organisations - including the Joseph Rowntree Foundation, Save the Children, Citizens Advice Bureau, the Salvation Army and the Trussell Trust - highlights the multiple negative impacts of making people wait such an extended period before accessing much-needed funds. If Universal Credit applicants can show a lack of adequate savings, the "Advance" must come in the form of a grant and not a loan. The government has commenced an inquiry to look into potential changes to the current five-week wait. ${ }^{1}$ Considering the unprecedented number of people accessing Universal Credit due to the finan-

1 The government have commenced an inquiry to look into potential changes with the closing date for submissions 17 April 2020: UK Parliament Committees, 
cial implications of COVID19, it is imperative that the government strikes the right balance between individual responsibility and providing an adequate safety net.

When those who have the least become laden down with problem debt, no-one benefits, apart from perhaps predatory commercial lenders. The situation increases problems for many other parts of our society, such as struggling charities and the NHS dealing with the physical and mental health complications of poverty and problem debt. These vulnerable individuals have few opportunities to "break free" from the cycle of debt, with bankruptcy processes often financially unaffordable and bureaucratically complex. The government has pushed the negative consequences of public debt onto those who can afford it the least, increasing inequality and indebtedness. Montgomerie's chapter suggests a bailout of harmful household debt, arguing for a debt jubilee and the targeted cancellation of the UK's personal debt stock. Whilst this may seem radical, this approach would bring much needed relief to citizens and a renewal of the wider macroeconomy. If we can justify bailing out financial institutions on the basis that they are "too big to fail", surely we can cancel the harmful household debt of those most in need on the basis that they are "too small to suffer".

\section{OVERVIEW OF THE BOOK}

This book makes the case for bringing the interdisciplinary fields of geography, law, and social policy together to explore low-income debt and austerity. The field of law is strengthened by examining political economy and the uneven nature of inequality and debt, the approach of geography has ignored legal studies for far too long and benefits from the close institutional analysis, and social policy can serve to bridge the disciplinary boundaries through the joint focus on debt and policy responses. The book is also informed by and created with debt-practitioners, who experience the realities of low-income debt. They have functioned as a sounding board, helped produce data and ideas, and written chapters which offer another view into the contingent and structural issues which surround these issues.

The first part explores the complex nature of the relationship between debt and austerity measures. The cultural acceptance of debt has deep roots, and Smith examines Margaret Thatcher's Right-to-Buy programme as the key to understanding the "normalisation" of debt. The reduction of the social safety net, the restructuring of the welfare system, and the dearth of legal aid has

Inquiry: Universal Credit: the wait for a first payment, available at https://committees .parliament.uk/work/135/universal-credit-the-wait-for-a-first-payment/. 
increased use of high-cost credit. These issues are examined from the perspective of class inequality, gender, and place. The first part also examines the problems and structure of the "debt industry", analysing the infrastructure of debt by exploring issues of consumer credit regulation, debt relief, debt advice, and credit scoring. It highlights broad themes of privatisation, and misconduct of privatised providers, and the legislature's reluctance to ensure adequate regulatory control of these areas. The beneficial economic effects of generous statutory debt relief are outlined, and it is argued that the increased reliance on privatised debt solutions impairs these effects. In particular, a number of chapters highlight that a privatised debt relief system is ill-suited to meeting the challenge of rebuilding our economy. Other themes concern the moral condemnation of financial failure. Negative attitudes towards over-indebted individuals are reflected in overly harsh debt relief systems, which are based on fears of moral hazard and a need to maintain "debtor discipline". These issues have been deliberately served by the rhetoric of conservative politicians, and are reinforced by widespread practices of credit scoring.

In the second part, we examine a range of potential approaches to address the challenges of debt. One of the simplest ways that this can occur is through tackling the harmful poverty premium and making sure that those on low-incomes do not unnecessarily pay more for goods and services. The high-cost credit is an important part of the current debt eco-system. Several potential solutions to the harms of these financial products have been put forward. This includes increased use of affordability assessments on inappropriate lending decisions, enhancing consumer credit regulation, and encouraging different bodies to work together to provide affordable alternatives. Another solution is a debt jubilee and the targeted cancellation of personal debt stock. Whilst these recommendations can all improve the current situation, the only clear and certain way to tackle the underlying issues of debt and austerity is to address the underlying cause, the inequality and poverty caused by the austerity measures. Unfortunately, the financial implications of the COVID19 crisis, make this unlikely and, in fact, the situation may get worse.

The main empirical analysis has been based on the UK, but the book also looks at Ireland, Sweden, Australia, the US, and other European examples. While there are unique aspects of the UK's experience with austerity and debt, it is clear that many wealthy developing countries are experiencing similar issues of poverty, increasing inequality, and the shrinking welfare state. For example, Grace's chapter on addressing financial exclusion in Australia highlights both the similarities and differences of the two countries. Despite very different natural environments, economic systems, and social welfare networks, the poverty levels experienced by the UK and Australia are exceptionally similar according to OECD data ( $11.9 \%$ and $12.1 \%$ respectively), and 
both countries have significant issues of financial exclusion that exacerbate pre-existing structural disadvantages.

In conclusion, the variation in potential solutions to low-income debt reflects the multiple and complex intersections between private and public forms of debt in an age of austerity. Direct austerity measures and an indirect "embrace" of austerity's ethos have led many states to enact similar approaches which have impacted debt at various scales of analysis. We explore how private debt in the global financial system became public sector debt following the 2008 financial crash, the uneven and unequal burden of austerity as the redistributive function of the state is reduced, and the numerous mechanisms of transmission of debt to the most vulnerable members of society, where the debt reappears as private debt. We also highlight the importance of the infrastructure of debt - the reduction of state funding for legal aid, the types of bankruptcy open to those without resources, and the disciplinary approach of using bailiffs, fines, and fees. Although there are many forms of poverty premium, we argue that the most important form of poverty premium is in the debt infrastructure itself - the numerous ways in which small debts, owed to the private or public sector, are allowed to escalate into large debts and into problem debt. Given the context of the ensuing COVID19 pandemic and the economic response of states and central banks, these issues will not be resolved any time soon. They will instead be exacerbated by another, larger round of state borrowing, money creation, and debt. This is the time to think through a different response - politically, economically, and socially. We think the chapters which follow will allow us to start that important conversation.

\section{BIBLIOGRAPHY}

Aalbers, M. 2009. "Geographies of the Financial Crisis", Area, 41: 34-42.

Aalbers, M.B. 2016. The Financialization of Housing: A Political Economy Approach. Routledge.

Alesina, A. and S. Ardagna. 2010. "Large Changes in Fiscal Policy: Taxes versus Spending" in J. Brown (ed.), Tax Policy and the Economy, vol. 24, Cambridge: National Bureau of Economic Research.

Alston, P. 2019a. Visit to the United Kingdom of Great Britain and Northern Ireland. United National General Assembly Report A/HRC/41/39/Add.1.

Alston, P. 2019b. United Nations General Assembly Report A/74/493.

Banting, K. and J. Myles, eds. 2013. Inequality and the Fading of Redistributive Politics. UBC Press.

Bar-Gill, O. 2004. "Seduction by Plastic", Northwestern University Law Review, 98 (4): $1373-434$.

Beswick, J. and J. Penny. 2018. "Demolishing the Present to Sell off the Future? The Emergence of 'Financialized Municipal Entrepreneurialism' in London", International Journal of Urban and Regional Research, 42(4): 612-32. 
Block-Lieb, S. and E.J. Janger. 2005-06. "The Myth of the Rational Borrower: Rationality, Behavioralism, and the Misguided Reform of Bankruptcy Law", Texas Law Rev., 84: 1481.

Blyth, M. 2013. Austerity: The History of a Dangerous Idea. Oxford University Press.

Bowcott, O. and P. Duncan. 2019. "Half of Magistrates Courts in England and Wales Closed since 2010" The Guardian, <www.theguardian.com/law/2019/jan/27/half-of -magistrates-courts-in-england-and-wales-closed-since-tories-elected $>$, accessed 13 April 2019.

Boyer, R. 2012. "The Four Fallacies of Contemporary Austerity Policies: The Lost Keynesian Legacy". Cambridge Journal of Economics, 36(1): 283-312.

Brenner, N. 2004. New State Spaces: Urban Governance and the Rescaling of Statehood. Oxford University Press.

Bulman, M. 2018. "Universal Credit: More than Half of People Denied Benefit have Cases Overturned on Appeal, Figures Show" The Independent $<$ www.independent .co.uk/news/uk/home-news/universal-credit-appeal-overturn-wrong-refused-benefit -poverty-dwp-a8649221.html> accessed 3 September 2019.

Cameron, D. 2010. Speech on the Big Society (Speech Delivered in Liverpool on 18 July 2010).

Center for Microeconomic Data (2020) Quarterly Report on Household Debt and Credit 2019, Q4 Reserve Bank of New York. <www.newyorkfed.org/medialibrary/ interactives/householdcredit/data/pdf/hhdc_2019q4.pdf> accessed 20 April 2020.

Chalkley, M. 2018. Funding for Justice 2008 to 2018: Justice in the Age of Austerity (Bar Council of England \& Wales).

Clifton, J., D. Diaz-Fuentes and A.L. Gómez. 2018. "The Crisis as Opportunity? On the Role of the Troika in Constructing the European Consolidation State", Cambridge Journal of Regions, Economy and Society, 11(3): 587-608.

Christopherson, S., Gertler, M. and Gray, M. 2014. "Universities in Crisis", Cambridge Journal of Regions, Economy, and Society. 7(2): 209-15.

Creutzfeldt, N. 2018. Ombudsmen and ADR: A Comparative Study of Informal Justice in Europe. Palgrave MacMillan.

Davidson, M. and W. Kutz. 2015. "Grassroots austerity: Municipal Bankruptcy from Below in Vallejo, California", Environment and Planning A: Economy and Space, 47(7): 1440-59.

Davidson, M. and K. Ward. 2014. "'Picking up the Pieces': Austerity Urbanism, California and Fiscal Crisis", Cambridge Journal of Regions, Economy and Society, 7(1): 81-97.

Davies, J.S. and I. Blanco. 2017. "Austerity Urbanism: Patterns of Neo-liberalisation and Resistance in Six Cities of Spain and the UK", Environment and Planning A, 49(7): 1517-36.

Department for Work \& Pensions. 2017. Universal Credit Statistical Ad Hoc: Payment Timeliness.

Donald, B. and M. Gray. 2017. "Urban Policy and Governance: Austerity Urbanism", in Bain, A.L. and Peake, L. (eds.) Urbanization in a Global Context. Oxford University Press. 89-102.

Donald, B. and M. Gray. 2019. "The Double Crisis: In what Sense a Regional Problem?", Regional Studies, 53(2): 297-308.

Donald, B., A. Glasmeier, M. Gray, and L. Lobao. 2014. "Austerity in the City: Economic Crisis and Urban Service Decline?" Cambridge Journal of Regions, Economy and Society, 7: 3-15.

Drake, C. 2017. Universal Credit and Debt. Citizens Advice. 
Dymski, G.A. 2012. "On the Origins of Subprime Loans, and How Economists Missed the Crisis" in Aalbers, M. (ed.) Subprime Cities: The Political Economy of Mortgage Markets. Wiley-Blackwell

Elgueta, G.R. 2013. "The Paradoxical Bankruptcy Discharge: Rereading the Common Law - Civil Law Relationship", Fordham Journal of Corporate \& Financial Law, 19 (1): 293-341.

Faria-e-Castro, M. 2018. Domestic Debt Before and After the Great Recession. Federal Reserve Bank of St Louis. <www.stlouisfed.org/on-the-economy/2018/october/ domestic-debt-before-after-great-recession>

Gilbert, D. 2018. "Legal Aid Advice Network 'Decimated' by Funding Cuts", BBC <www.bbc.co.uk/news/uk-46357169> accessed 12 December 2018.

Goodnight, G.T., D. Hingstman and S. Green. 2015. "The Student Debt Bubble: Neoliberalism, the University, and Income Inequality", Journal of Cultural Economy, 8(1): 75-100.

Gray, M. and A. Barford. 2018. "The Depths of the Cuts: The Uneven Geography of Local Government Austerity", Cambridge Journal of Regions, Economy and Society, 11(3): 541-63.

Hall, S. and A.E. Jonas. 2014. "Urban Fiscal Austerity, Infrastructure Provision and the Struggle for Regional Transit in 'Motor City"', Cambridge Journal of Regions, Economy and Society, 7(1): 189-206.

Hallinan, C.G., 1986. "The Fresh Start Policy in Consumer Bankruptcy: A Historical Inventory and an Interpretive Theory", University of Richmond Law Review, 21 (49): 49-141.

Hamnett, C. 2014. "Shrinking the Welfare State: The Structure, Geography and Impact of British Government Benefit Cuts", Transactions of the Institute of British Geographers, 39(4): 490-503.

Harvey, D. 1989. "From Managerialism to Entrepreneurialism: The Transformation in Urban Governance in Late Capitalism", Geografiska Annaler: Series B, Human Geography, 71(1): 3-17.

Harvey, D. 2012. "The Urban Roots of the Financial Crisis" in Aalbers, M. (ed.) Subprime Cities: The Political Economy of Mortgage Markets. Wiley-Blackwell.

Hastings, A., N. Bailey, G. Bramley and M. Gannon. 2017. "Austerity Urbanism in England: The 'Regressive Redistribution' of Local Government Services and the Impact on the Poor and Marginalised", Environment and Planning A, 49: 2007-24.

Herndon, T., M. Ash and R. Pollin. 2014. "Does High Public Debt Consistently Stifle Economic Growth? A Critique of Reinhart and Rogoff", Cambridge Journal of Economics, 38(2): 257-79.

House of Commons Justice Committee. 2015. Impact of Changes to Civil Legal Aid under Part 1 of the Legal Aid, Sentencing and Punishment of Offenders Act 2012: Eighth Report of Session 2014-15. House of Commons.

Kempson, E., S. Collard and N. Moore. 2004. Fair and Reasonable: An Assessment of the Financial Ombudsman Service. Personal Finance Research Centre.

Kinsby, B. 2010. “The Big Society: Power to the People?", The Political Quarterly, 81: 484-91.

Kitson, M., R. Martin and P. Tyler. 2011. "The Geographies of Austerity", Cambridge Journal of Regions, Economy and Society, 4(3): 289-302.

Konzelmann, S.J. 2019. Austerity. John Wiley \& Sons.

Konzelmann, S.J., M. Gray and B. Donald. 2016. "Assessing Austerity”, Cambridge Journal of Economics, 38(4), 1-15.

Krugman, P. 2015. “The Austerity Delusion”. The Guardian, 29 April 2015. 
Lane, J., B. McCay and M. Thorne. 2018. Hidden Debts: The Growing Problem of Being Behind on Bills and in Debt to the Government. Citizens Advice Bureau.

Liverpool City Council. 2017. Universal Credit: Unintended Consequences.

Lowe, S.G., B.A. Searle and S.J. Smith. 2012. "From Housing Wealth to Mortgage Debt: The Emergence of Britain's Asset-shaped Welfare state", Social Policy and Society, 11(1): 105-16.

Martin, R. 2011. "The Local Geographies of the Financial Crisis: From the Housing Bubble to Economic Recession and Beyond", Journal of Economic Geography, 11: 587-618.

McClanahan, A. 2011. "The Living Indebted: Student Militancy and the Financialization of Debt", Qui Parle: Critical Humanities and Social Sciences, 20(1), 57-77.

McDonagh, E., R. Derricourt and T. Baker. 2019. The Rules of Enforcement: Making a Complaint about the Behaviour of Bailiffs in a Self-regulated System. Citizens Advice Bureau.

Mian, A. and A. Sufi. 2014. House of Debt. University of Chicago Press.

Montgomerie, J. and M. Büdenbender. 2015. "Round the Houses: Homeownership and Failures of Asset-based Welfare in the United Kingdom", New Political Economy, 20(3): 386-405.

Möser, K., 2019. "Making Sense of the Numbers: The Shift from Non-consensual to Consensual Debt Relief and the Construction of the Consumer Debtor", Journal of Law and Society, 46(2): 240-70.

National Audit Office. 2020. Local Authority Investment in Commercial Property. Report by the Comptroller and Auditor General. February, 2020.

Office for National Statistics. 2018. UK Government Debt and Deficit, December 2018. Available online at: <www.ons.gov.uk/economy/governmentpublicsectorandtaxes/ publicspending/bulletins/ukgovernmentdebtanddeficitforeurostatmaast/ december2018> accessed 5 May 2019.

Peck, J. 2012. Austerity Urbanism: American Cities under Extreme Economy. City, 16(6): 626-55.

Peck, J. 2014. "Pushing Austerity: State Failure, Municipal Bankruptcy and the Crises of Fiscal Federalism in the USA", Cambridge Journal of Regions, Economy and Society, 7(1): 17-44.

Pike, A. and J. Pollard. 2010. "Economic Geographies of Financialization", Economic Geography, 86(1): 29-51.

Pike, A., P. O'Brien, T. Strickland and J. Tomaney. 2019. Financialising City Statecraft and Infrastructure. Edward Elgar Publishing.

Pistor, K. 2020. "Why Debt Relief should be the Answer to this Coronavirus Crash". The Guardian, 18 March 2020.

Plender, J. 2020. "The Seeds of the Next Debt Crisis". Financial Times, 4 March 2020. $<$ www.ft.com/content/27cf0690-5c9d-11ea-b0ab-339c2307bcd4>

Prescott, N. 2018. "How Austerity is Killing Legal Aid and Restricting Access to Justice". The Meteor <www.themeteor.org/2018/09/05/how-austerity-is-killing -legal-aid-and-access-to-justice/> accessed 5 May 2019.

Ramsay, I. 2000. "Market Imperatives, Professional Discretion and the Role of Intermediaries in Consumer Bankruptcy", American Bankruptcy Law Journal, 74: 399-460.

Ramsay, I. 2003. "Interest Groups and the Politics of Consumer Bankruptcy Reform in Canada", University of Toronto Law Journal, 53: 379-423.

Ramsay, I. 2017. Personal Insolvency in the 21st Century. Bloomsbury. 
Reese, L.A., G. Sands and M. Skidmore. 2014. "Memo from Motown: Is Austerity here to Stay?", Cambridge Journal of Regions, Economy and Society, 7(1): 99-118.

Reinhart, C. and K. Rogoff. 2009. This Time is Different: Eight Centuries of Financial Folly. Princeton University Press.

Reinhart, C. and K. Rogoff. 2010. "Growth in a Time of Debt", American Economic Review: Papers and Proceedings, 100: 573-78, <http://scholar.harvard.edu/files/ rogoff/files/growth_in_time_debt_aer.pdf> accessed June 2019.

Ross, A. 2013. "Mortgaging the Future: Student Debt in the Age of Austerity", New Labor Forum, 22(1): 23-28.

Slater, T. 2016. "Revanchism, Stigma, and the Production of Ignorance", Housing, 31, 23-48.

Slocock, C., R. Hayes and D. Harker. 2015. Whose Society? A Final Big Society Audit (Civil Exchange and DHA, in conjunction with Joseph Rowntree Charitable Trust and the Barrow Cadbury Trust).

Spooner, J. 2019. Bankruptcy, The Case for Relief in an Economy of Debt. Cambridge University Press.

Stiglitz, J.E., J.P. Fitoussi, P. Bofinger, G. Esping-Andersen, J.K. Galbraith and I. Grabel. 2014. "A Call for Policy Change in Europe", Challenge, 57(4): 5-17.

Streeck, W. 2014. "The Politics of Public Debt: Neoliberalism, Capitalist Development and the Restructuring of the State", German Economic Review, 15(1): 143-65.

Sunstein, C.R. 2006. "Boundedly Rational Borrowing: A Consumer's Guide", University of Chicago Law Review, 73(1): 249-270.

Svallfors, S. and A. Tyllström. 2019. "Resilient Privatization: The Puzzling Case of For-profit Welfare Providers in Sweden", Socio-Economic Review: 17(3): 745-765.

Tabb, W.K. 2014. "The Wider Context of Austerity Urbanism”, City, 18(2): 87-100.

The Centre for Social Justice. 2020. Collecting Dust: A Path Forward for Government Debt Collection.

Theodore, N. 2020. "Governing Through Austerity: (Il) Logics of Neoliberal Urbanism after the Global Financial Crisis", Journal of Urban Affairs, 42(1): 1-17.

Wacquant, L. 2009. Punishing the Poor, The Neoliberal Government of Social Insecurity. 2nd ed., Duke University Press.

Wherry, F.F. 2019. "Household Finances and Credit Visibility" in F.F. Wherry and I. Woodward (eds.), The Oxford Handbook of Consumption. Oxford University Press"

Wood, G., S. Parkinson, B. Searle and S.J. Smith. 2013. "Motivations for Equity Borrowing: A Welfare-switching Effect", Urban Studies, 50(12): 2588-607. 